This is a post print version of an article published by SAGE in Journal of Social Work 10(1)

2010, pp. 59-79. Available online:

http://journals.sagepub.com/doi/abs/10.1177/1468017309350657

Kirsi Juhila, Christopher Hall \& Suvi Raitakari

\title{
ACCOUNTING FOR THE CLIENTS' TROUBLESOME BEHAVIOUR IN A SUPPORTED HOUSING UNIT
}

Blames, excuses and responsibility in professionals' talk

\begin{abstract}
Summary: The paper studies how professionals working in a Finnish supported housing unit explain the behaviour of clients which they define as troublesome in regard to rehabilitation expectations. The clients of the unit suffer from mental health and substance abuse problems. The research data consist of 23 meetings where clients' progress is discussed and were analysed using accounts analysis.

Findings: There were 225 episodes where the professionals explain the clients' troublesome behaviour. Three ways of accounting appeared with similar frequency: 1) blaming clients for their behaviour, 2) excusing clients' behaviour, 3) excusing clients and blaming others for the clients' behaviour. Detailed analysis of the data shows how these ways of accounting are used in the meeting talk and how blame, excuses and responsibility are combined in different ways. Another important finding is that the same troublesome behaviour can be accounted for in several ways in the course of meeting conversations.

Applications: The analysis displays the complex ways in which policy imperatives and professional ethics are routinely managed in everyday situations. Whilst concepts like self determination and choice promote clients' control of their care, in practice client careers are
\end{abstract}


affected by locally negotiated judgements. The study of policy implementation can benefit from discourse-oriented approaches.

Key words: rehabilitation, troublesome behaviour, accounts analysis, responsibility, self determination

\section{INTRODUCTION}

This paper studies the ways in which professionals working in a Finnish supported housing unit account for their clients' troublesome behaviour. The aim is to carry out a data-driven analysis of the some of the everyday conversational practices which occur in the unit. Troublesome behaviour is defined as action by the clients that the professionals construct as undesirable in terms of rehabilitation expectations. Accounting involves constructing explanations of this kind of behaviour, which professionals do in terms consistent with their role as human service experts. They are locating problems and their causes, making assessments and diagnoses in order to find possible remedies for the problems at hand (White, 2003: 191). This type of accounting is continually present in everyday work, drawing on professional theories, practice experience and common sense explanations. The task of research is to make these common, but often unnoticed accounting practices visible (Garfinkel, 1967; Pithouse, 1987). Such an approach reveals the importance of peer support in enabling professionals to make sense of their everyday work. It further shows how principles like self determination and choice are constantly compromised when faced with practice exigencies. 


\section{RESEARCH CONTEXT AND DATA}

In the 2000s, significant changes have occurred in Finland as regards to the need for and organisation of mental health and substance abuse services. There has been a trend to develop psychiatric care and substance abuse work away from hospitals and institutions towards a greater reliance on community services. As a result of these developments, a number of new services aimed at rehabilitation have been established, primarily in the form of units based on supported housing. The context of this research is a supported housing unit situated in a large Finnish city.

The supported housing unit has been operating since 2004. It offers a community-based alternative to living in hospitals or nursing homes for people who suffer from both mental health and substance abuse problems. The principle aim of this intervention is to strengthen the clients' ability to lead normal and independent lives, in other words to rehabilitate them. Rehabilitation is based on the discourse of normalisation; after having spent a reasonable time in the unit the clients are expected to integrate to the society as more self-caring citizens (Raitakari, 2008; Sariola \& Ojanen 2000). The unit is not meant to be a permanent placement.

The unit is part of a larger mental health organisation, which as a third-sector actor is providing services to the local authority (municipality). It is located in a conventional high-rise housing estate, where 15 ordinary flats have been reserved for the unit's clients. A facility called 'support centre' located in the same area functions as a meeting point for the clients and the professionals. The clients may visit the support centre at any time during its opening hours, where the professionals organise group and work activities. The workers also make visits to the clients' 
homes and participate in multi-professional discussions. The five professionals employed in the activity have previous experience of both social and mental health work.

This study is part of a larger research project which has been looking at the construction of control and support in the everyday practices of social welfare work (Jokinen \& Juhila 2008; Juhila, forth.). The supported housing unit has collaborated in the research project since it opened. One of the researchers (Suvi Raitakari) has been making ethnographic observations, interviews and tape-recordings of naturally occurring conversations in the unit during all this time.

The research data used in this study consist of 23 meetings among the professionals. The average length of the meetings is 80 minutes, and all the workers are present. The researcher is also present, but doesn't contribute to the content of the talk. In the meetings, 15 different clients are talked about, of which about nine are mentioned at each meeting. The clientele of the unit is male-dominated; only two of the 15 clients are women. All the meetings follow the same schedule. They start with a discussion of general issues related to the unit's activity, followed by the main part of the meeting, during which the workers discuss, one by one, the current situation of each client. This case talk discussion does not have a pre-set agenda. It is initiated by the client's key worker, but after that (s)he doesn't take any extra authority in the course of the discussion. The purpose of the talk is to update information about the clients and assess their possible progression or regression and the causes, in other words to make sense of the cases (Pithouse, 1985; Riemann, 2005). The clients themselves are not present at the meetings. Thus, the meeting conversations are backstage talk (Goffman, 1959), in which the professionals produce descriptions and narratives about absent clients (Nikander, 2003). The conversations in 
the meetings can also be characterised as shared consultations among colleagues. There are no managers of the main mental health organisation present; all the participants are involved in the unit's direct work with the clients being discussed.

In addition to the meetings studied here the clients' progress is assessed in a formal way in the executive group of the unit, which has been established by the main organisation. Eventually the unit is also accountable for its results to the municipality (to the financier of the service) and has to produce textual reports for this purpose. In the discussion part of the text we consider whether this accountability to the executive group and to the municipality is present in the meetings talk and in what ways.

\section{ACCOUNTS ANALYSIS AND RESEARCH QUESTION}

The study relates to a research genre which focuses on language and social interaction of social and human service work practices (e.g., Jokinen et al., 1999; Hall et al., 2003; D'cruz 2004; White \& Stancombe, 2003; Parker, 2005; Hall et al., 2006). When studying practices we draw on discursive constructionism but apply also some conversation analytical ideas based on ethnomethodology (see Buttny, 2004: 4-9). Clients' troublesome behaviours are not taken as granted as factual events but the focus is on the ways that the clients' problems get told and are jointly constructed by the professionals (c.f. Buttny, 1996; Buttny \& Ellis, 2007). Following Maynard (1988: 318) we aim to supply an understanding of how the professionals "procedurally produce and experience forms of 'trouble' that may emerge as problems and deviance'. So, instead of seeing social problems and power as abstractly, theoretically or structurally defined, 
we look at the 'interaction order' as its own right and how context is constructed in everyday activities (Goffman, 1983; Maynard, 1988).

Buttny $(2004,2)$ writes, that 'problems can be told through various actions such as narratives, claims, descriptions, accusations, complaints and the like'. For instance, accounting for problems can be carried out through telling stories which exemplify individual clients' doings and nondoings (Hall, 1997:11). Accounts are interactional achievements by the participants. Approaching accounts as joint action' here and now' means that versions of the clients' problems and troubles can be examined in terms of the extent to which they are re-produced and re-negotiated.

The concepts of account and accounts analysis can be used in either a broad or a narrow sense (Buttny, 1993: 14-5). In a broad sense, accounts are seen to be present in all everyday discourse, such as in self-presentation and in describing things (e.g. Antaki, 1994). As Garfinkel (1967: 33) notes speakers routinely build into their talk accountable formulations which prepare rebuttals to potential criticisms. Accounts can then refer generally to any passage of talk and writing. Garfinkel (1967: 33) writes: 'any setting organizes its activities to make its properties as an organized environment of practical activities detectable, countable, recordable, reportable, tell-astory-aboutable, analyzable - in short accountable'.

In a narrower sense accounts refer to 'explaining actions which are unusual, bizarre or in some way reprehensible' (Potter and Wetherell, 1987: 74). Accounts analysis focuses then on the causes of actions as the products of human reasoning and analysis done in situ (Eglin \& Hester, 2003: 47-48). The origin of the latter formulation is found in an article published in 1968 by Scott and Lyman. In this research we draw on Scott and Lyman's (1968: 46) definition of an account: 
By an account, then, we mean a statement made by a social actor to explain unanticipated or untoward behaviour - whether that behaviour is his own or that of others, and whether the proximate cause for the statement arises from the actor himself or from someone else.

From the point of view of this study the essential part in this definition is that accounts are understood as statements given when there is a gap between action and expectations (Scott \& Lyman,1968: 46; Hall et al., 2006: 18). This means that we will concentrate on accounts presented and co-constructed by the professionals to explain client behaviour which they define as troublesome in regard to rehabilitation and normalisation expectations. Scott and Lyman's definition covers explanations of both one's own and someone else's behaviour. Among these options this study focuses on the latter one, on accounts given by the professionals for their clients' behaviour. The research design would be different if the clients themselves were present to explain the behaviour regarded as troublesome by the professionals (e.g. Auburn \& Lea, 2003; Kurri \& Wahlström, 2005; Mäkitalo, 2003; Silverman, 1987; Slembrouck \& Hall, 2003; Stancombe \& White, 2005; Urek, 2005).

The accounts analysis first identified all episodes of discussion in the meetings, where the professionals try to explain a gap between the clients' behaviour and the professionals' expectations. This resulted in 225 such episodes, demonstrating how frequently episodes of troubles talk appear in the meetings. Besides this talk the professionals use almost as much time for discussing the progress of their clients. Examining this progress talk is, however, a topic for another analysis. The next stage of analysis specified the type of client behaviour that is defined by the professionals as being against their wishes and thus troublesome. The professionals co- 
constructed as troublesome five kinds of behaviour: 1) breaking the more or less expressed rules of the unit (e.g. not keeping to agreements, not committing to the unit, uncommunicativeness, keeping to oneself), 2) substance use that is beyond control, 3) unhealthy living (e.g. disregard of personal hygiene, neglected illnesses, gaining weight), 4) failings in everyday living (e.g. not cleaning one's flat, problems in using money and in time management), 5) general lack of independence and initiative in life.

After these preliminary steps followed the core of the accounts analysis. This explored what kind of accounts are constructed when the professionals explain their clients' troublesome behaviour, and how these accounts are produced and shifted in the course of discussion in meetings. Following Silverman's (2007: 56) advice for qualitative researchers we focus on what professionals do in the meetings; what they say is 'an activity awaiting analysis and not a picture awaiting commentary'. The analysis shows that the accounts are concerned with locating responsibility for the behaviour in terms of blame or excuses, or both. Scott and Lyman (1968: 47) define excuses 'as accounts in which one admits that the act in question is bad, wrong, or inappropriate but denies full responsibility'. Blame, on the other hand, can be regarded as accounts in which troublesome behaviour is explained as due to omissions or commissions for which the actors can be held responsible (cf. Hall et al., 2006: 34; Pomerantz, 1978).

The professionals display three ways of accounting for troublesome client behaviour, in which excuses, blames and responsibility are interrelated. The ways of accounting are: 1) blaming clients for their behaviour, 2) excusing clients' behaviour, 3) excusing clients and blaming others for the clients' behaviour. Quantitatively, the frequency of each type is approximately the same in the data. The following analysis provides a detailed examination of the content of each method of 
accounting, how they are produced in conversation, and how one type of account may shift to another during the course of conversations.

The excerpts from the meetings are selected to represent the range of co-constructed accounts displayed in the data. The meeting talk was transcribed verbatim. The actual names of the clients have been changed to fictitious ones. All references to localities and services that might risk the anonymity of the persons involved have been removed. The original language in the meetings is Finnish, but the excerpts have been translated to English for the purposes of this paper. Transcribing is always an imperfect process which constructs one kind of textual interpretation of real talk and conversation. Making a translation from original language brings an additional dimension to this interpretation (Nikander, forth.). However, while recognising this imperfection, in the translation process, we aim to present the original meanings of the accounts and the ways they are talked into being as accurate as possible. The transcription symbols used are:

$$
\begin{aligned}
& {[=\text { overlapping speech }} \\
& \text { underlining = emphasis }
\end{aligned}
$$

(1) $=$ pauses in seconds

$(($ laugh $))=$ a comment added by the transcriber

P1, P2 etc. = professionals (for the reasons of anonymity a same number does not refer to a similar professional in different excerpts)

\section{BLAMING CLIENTS FOR THEIR BEHAVIOUR}

In the account episodes where the professionals blame the clients themselves for the gaps between action and expectations, troublesome behaviour is explained as due either to the clients' 
attitudes or their chosen ways of living. The first excerpt from the data shows an explanation based on the client's way of life:

\section{Excerpt 1}

P2: what about his daily life for I remember from earlier times that it was his dad who used to see every weekend that his fridges were stocked up and (1)

P4: well it was er last time I visited him it was upsetting in the sense that all of the cupboards were completely bare he had nothing there he had run out of everything ((indistinct)) so I gave him some (4) well shall I tell you what money it was that I gave him 80 cents from and said that you're to go shopping and buy some cereal so you can have some porridge for supper ((indistinct))

P3: but what does he spend his money on if it isn't food and yet he receives tens of euros every week

P1: we all know the answer you can imagine for yourselves what the money is spent on ((overlapping indistinct talk))

P3: but how can a person both study and drink that's an impossible equation for me ((in an annoyed tone))

In this conversation, it is unhealthy living that is depicted as troublesome behaviour; the client does not pay enough attention to how he eats. Professional 4 reports having noted this problem most recently when visiting the client at his home. The observations made during the home visit construct the fact of the eating problem (Smith, 1978). There was no food in the cupboard and the professional reports that she had had to resort to emergency aid, in other words, to giving the client a small sum of money to buy cereal. The construction of the actual account concerning the problematic behaviour begins with Professional 3's question, wondering about the disparity between the funds available to the client and the bare cupboard. In response another professional invokes shared knowledge about the client: 'we all know the answer'. The answer is revealed in 
the following turn, which Professional 3 again formulates as a question, simultaneously moving on to another topic. She wonders how a person is capable of studying and supporting a drinking habit at the same time. The reference to drinking expresses the answer that the professionals 'all know': the client's money goes on alcohol. It is possible to read into this turn a suggestion of personal choice. It is the client's way of life to prefer to use his money for alcohol rather than food. Because of this choice, he is defined as being personally responsible for his unhealthy way of life.

In another 'blaming clients' excerpt the professionals explain the client's behaviour by his attitudes:

\section{Excerpt 2}

P2: Matti made lasagne yesterday together with you then

P1: yeah

P3: did he come and eat

P2: no no he didn't then

P1: he had none of it himself

P4: oh dear

P3: oh dear indeed

P2: so I thought that I won't go phoning him this time he [knows that

P1: [yes we'll not we won't call him not we

P2: and now it isn't sort of

P1: he has a calendar it's in his weekly calendar what he should commit to if he can't commit to those things

P2: $\mathrm{mm}$

P1: he's having a trial period now [remember that

P3:

[well I do think he is 
P1: all the time

P3: he cooks the meal himself he could also come and he should commit to that as well is my opinion

P1: well it's his choice

P2: but his choice I thought that I just won't the guy's cooked the meal himself he knows perfectly well when it's going to be eaten so if he doesn't show up he won't (1) I simply won't start calling him

((background talk by P1 showing agreement, such as 'yeah'))

In this excerpt, lack of commitment to the unit and disregard for agreed rules are defined as troublesome behaviour. One of the central rules in the unit is participation in shared activity, for rehabilitation through community forms the basic ideological pillar of the unit. The client in question has missed out on the unit's common mealtimes, even though he has taken part in preparing the meal. How do the professionals explain this problematic behaviour? The account is crystallised in the two final turns, in which his lack of commitment is defined as a personal choice. When such non-commitment to joint activity is defined as stemming from the client's personal attitudes and choices, he is also inevitably blamed for it. In this case, blame may have major consequences. About halfway through the excerpt, Professional 1 reminds the others that the client is on a trial period at the unit, using an emphasized tone. Furthermore Professional 2 then appears to withdraw encouraging practices, it is now up to the client. The implication is that a client who remains uncommitted to the activity for reasons of his own is in danger of being discharged from the unit, unless his attitude changes.

Richard Buttny (1993: 3) writes that 'persons are taken to be more responsible for what they can control'. This is exactly what the excerpts analysed above are about. The professionals construct the clients as blameworthy by appealing to actions that the clients themselves could control: they 
could change their ways of living and attitudes if they only wanted to. Because they could control the causes of troublesome behaviour, they are ultimately responsible for their own behaviour. Beside the irresponsible clients, the professionals themselves appear as responsible persons. They have done all they can, but the clients are uncooperative with regard to the rehabilitation aims of the unit (cf. Hall et al., 2006: 49; Juhila, 2003). The 'blaming the clients' account and the emphasis on the clients' responsibility are thus bound together. We can also see that choice is interpreted as challenging the rules of the unit rather than an act of self independence, highlighting the dilemmas of balancing rules and principles. Baistow (1994: 45) notes 'empowerment' as having both liberating and regulatory possibilities.

\section{EXCUSING CLIENTS’ BEHAVIOUR}

When presenting excuses for their clients' troublesome behaviour, the professionals produce explanations for the gap between action and expectation that reduce the clients' blameworthiness, by appealing to either to the clients' inadequate cognitive skills or to their illnesses, mostly mental health problems (cf. White, 2002). In the third excerpt, inadequacy of cognitive skills is constructed as an explanation:

\section{Excerpt 3}

P2: well he does potter about he does we actually left here only ten past eight yesterday because Henry was so (1) it's as if he has no concept of time really I mean he sort of cannot take others into account in that respect

P1: mm (1) but on the other hand it that's part of his personality then it ought to be turned to advantage somehow (1)

P2: yes 
P1: in his care plan

P3: see to it that he has time ((short laugh))

The troublesome behaviour discussed here consists of Henry's continuous tardiness, which causes difficulties for others in the unit. The excerpt describes a situation where a group about to leave for the swimming baths had to wait for Henry and were only able to leave for their joint outing later than the agreed time. Here, explaining the problematic behaviour could progress to blaming the client, perhaps by referring to his careless attitudes or way of life, as was the case in Excerpts 1 and 2. However, the conversation takes another direction, as Professional 2 presents an excuse related to the client's inadequate cognitive skills:' it's as if he has no concept of time really, I mean he sort of cannot take others into account in that respect'. This is a fault that Henry himself cannot help. The same fault also constructs an excuse for not being able to take others into account. This is a matter of not knowing how, rather than intentional negligence. In the next turn, the responsibility for Henry's behaviour is, at least in part, transferred to the professionals themselves. If poor time management is defined as part of Henry's personality, then rehabilitation, that is the care plan, must be based on this 'fact'.

A mental health problem is constructed as an excuse in the next excerpt:

\section{Excerpt 4}

P4: I suppose you'd have to stand next to him and teach him

P?: well yes

P2: here's your soap and here's your shampoo ((ironically)) (2)

P3: well he does wash then if he's got like he does know how to wash himself bu-

P4: but he's somehow you know regressed now

P3: it's the illness that makes him so 
P4: that's the way it is he's one of our most difficult clients paranoid schizophrenia (2) ((background talk showing agreement, such as 'yeah'))

P1: you can tell by the fact that he's not really capable of accepting feedback

In the professionals' talk, the troublesome behaviour of this client consists of a lack of independence and the associated problems of everyday living. For example, Professionals 4, 2 and 3 jointly construct a description of how getting oneself washed requires external direction. The excusing account begins after this general description, with a turn by Professional 4, in which she begins to think about the causes of this lack of initiative. Her comment about regression hints that the gap between action and expectations was not always this big. Something has happened to make the situation worse. Professional 3's turn continues on this topic and constructs the supposed change as something over which the client has had no influence and for which he cannot therefore be held responsible. The cause of the regression is defined as an illness, paranoid schizophrenia. For her own part, Professional 1 gives evidence of the progress of the illness by presenting her observations on the client as incapable of accepting feedback. The incapability is defined as a sign of illness, not as, for example, the client's indifference towards feedback from the professionals (cf. Watson, 1978: 112).

According to Scott and Lyman (1968: 48), one defence against accusations is that the 'will' of the persons accused are not completely free. Buttny (1993: 2) develops this idea by saying that free choice is presumed to be a necessary condition for responsibility. Inadequate cognitive skills and (mental) illnesses can be understood as obstacles to exercising one's free will. Following this logic of accounting, clients who engage in dependent, rule-breaking, substance-abusing behaviour may wish to abandon these characteristics or habits and live as expected and desired, 
but the level of their skills and abilities prevent this wish from being fulfilled. Their inabilities and illnesses are used to excuse troublesome behaviour, and furthermore, to alert the workers to acknowledge such constraints on their care plan. In the 'excusing the clients' behaviour' account the clients' troublesome behaviour is not overlooked, but their blameworthiness and responsibility is mitigated (Hall et al., 2006: 18; Watson, 1978).

\section{EXCUSING CLIENTS AND BLAMING OTHERS FOR CLIENTS’BEHAVIOUR}

The professionals also excuse their clients' troublesome behaviour by blaming others. In these accounts the professionals construct the clients' informal or formal social networks as the cause of trouble. Among informal networks the blame is placed on the clients' families and 'bad' company. As for formal networks, those accused are various social and health service systems and their actors, including the supported housing unit itself.

Let us start with an excerpt where the professionals blame the client's informal network for his lack of independence:

\section{Excerpt 5}

P1: the way his mother relationship is

P2: well the mother relationship is indescribable ((sound of 'huh'))

P2: (1) how should I describe it well indescribable it's like the mother the mother treats Ari thirty years of age more or less as if

P1: [he was a little boy

P2: [he was three, like all that's missing is that she washes him

P1: she does actually [sometimes during the weekend

P1: $\quad$ [fusses over him turns his trouser legs up (2) oh Ari, look at 
your trouser legs and really it's absolutely shocking the communication that P1: cutting the cord might be a sort of goal here then

Turn by turn, Professionals 1 and 2 jointly construct an interpretation of the client's abnormal relationship with his mother as troublesome, since it restricts Ari's potential to act independently. The abnormality is produced, above all, by comparing the client's age with the manner in which the mother is described to treat her son. The treatment is similar to how mothers generally treat a small child or a three-year-old. Thus, the conflict lies in the fact that Ari, 30 years, receives care that in normal mother-child relationships would be natural during infancy. As evidence of the abnormal caring relationship the professionals present three concrete examples: on occasion during weekends, the mother has washed Ari, she looks after Ari's clothing and communicates as one would with a child. The professionals use strong expressions like 'indescribable' and 'absolutely shocking' to describe the relationship to emphasise the abnormality of the situation. In this excerpt it is expressly the mother that is described as maintaining an undesirable relationship. The mother is active: the mother holds, washes, looks after and communicates. Ari is allocated the role of a passive recipient, a sort of victim's position. The mother's 'blameworthiness' thus produces an excuse for Ari's lack of initiative. As a solution, Professional 1 actually suggests that the mother-son relationship should be changed, 'cutting the cord might be a sort of goal here then'.

In the next excerpt the gaze turns to the professionals themselves.

\section{Excerpt 6}

P1: I was thinking that we could have a breathalyzer here as well

P2: yes a breathalyzer would really be a 
P1: like take someone like Klaus Maijanen you don't know how many mornings he's come here in God knows what state so

P2: yes

P1: you don't know what the reason is so you could at least verify something and we'd be able to see and know that

P3: the way I see it is that it'd be taken care of somehow by the home work team or the doctors the people would go some place for those tests

P1: only it doesn't work that way

P3: so we'll have to test them here then

P1: it's on the other hand the people expect that control and that that it's found out things like hey, what do you know Klaus Maijanen is drinking

Before this excerpt the professionals have discussed the clients' use of alcohol, and the problems and dangerous situations associated with it. In the light of the professionals' expectations related to rehabilitation, the clients' alcohol behaviour is not satisfactory, which is why it is necessary to discuss its causes and the possible interventions. Professional 1 suggests that one solution would be to buy a breathalyzer for the shared facilities at the unit and is immediately seconded by Professional 2. Professional 1 continues arguing for her solution by appealing to an authentic case, Klaus Maijanen, who sometimes appears in the common room ' in God knows what state'. The breathalyzer would give proof of his condition and would indicate to the client that the professionals do see and know about his intoxication. However, Professional 3 is lukewarm about the proposal and questions it in her turn. She is not in favour of testing the use of intoxicants at the unit and by the unit staff. It would be better if the testing was done 'some place' by other professionals. The professional who originally voiced the idea reacts to this immediately by pointing out that this practice would not work. Professional 3's next turn, 'so we'll have to test them here then', does not indicate complete agreement, but is no longer challenging the idea. 
After this, Professional 1 presents a new argument in support of her proposal, this time invoking client orientation. The clients more or less expect control of this kind, so as to make their alcohol use known. Looking at this turn it is possible to infer the following chain of conclusions: control, that proves that the clients drink, and consequently intervening with the problem, is all in the clients' interests as well, and more or less what the clients' themselves hope for. From this viewpoint, non-exercise of control and non-intervention are problematic practices and, at worst, help to maintain their drinking habit. Thus the professionals should partly blame themselves for the clients' problematic behaviour.

In the way of accounting analysed above, responsibility for the clients' troubles is allocated to other people who behave improperly or badly, sometimes including the professionals themselves. Scott and Lyman's (1968: 50) name for an accounting that looks for explanation in others' behaviour is scapegoating. Scapegoating is not, however, the appropriate term in this context, because it is usually used in situations where people under a threat of blame try to reduce their own responsibility by accusing someone else in a weaker position. The term also implies that the one accusing others is in the end regarded as the guilty one. In the excerpts analysed above the professionals blame other people for the clients' behaviour on behalf of the clients. It can be argued that this kind of 'on behalf accounting' produces stronger excuses for the clients than would be a case if the clients themselves blame others for their own unwanted actions. When localising the cause in formal networks, the interlocutors create an interpretation of the professionals' (mis)management which works as an excuse for the clients and mitigates their blameworthiness (White, 2003). The function is the same when informal networks are constructed as responsible for the clients' troublesome behaviour. 


\section{SHIFTING BETWEEN BLAMES, EXCUSES AND RESPONSIBILITY}

The three ways of accounting presented and analysed above are not anchored to particular troublesome behaviours in the meeting talk. Even similar behaviour can be accounted for in different ways, depending on the conversational context (Buttny, 1993: 5-6). In the course of conversations one form of accounting often merges into another, when the professionals challenge one explanation of troublesome behaviour by expressing another possible cause of the behaviour:

\section{Excerpt 7}

P4: personally I also consider it sort of important that Esa should be ((indistinct speech)) I mean that we should be sort of interested in his you know how he feels and have the patience to listen for Esa is I think he's a bit you know he tends to complain

P1: yes

P2: he keeps on moaning about things

((overlapping talk during which several workers repeat the word 'moan'))

P4: he moans and groans somehow but really he does moan about the weekends even if they'd been fun in some ways he'll still think of everything that wasn't

((background talk showing agreement, such as 'yeah'))

P3: I guess he must have sort of learned that negativity

The troublesome behaviour which the professionals have constructed before this conversation consists of Esa's lack of initiative or goals in his life. In this brief passage, three accounts are produced for Esa's behaviour. In the first turn the gaze is directed to the activity of the professionals themselves. Here, Professional 4 reminds the others of the task of the unit staff: 'we should be sort of interested in his you know how he feels and have the patience to listen for Esa'. 
When saying this she produces an instruction for the professionals and self-reflectively suggests that they may not always have shown sufficient interest. In this way, she excuses the client's behaviour by shifting part of the blame on to the professionals themselves. However, the perspective is changed in the same turn, and the new explanation constructed is the client's own attitude based on complaining. Professional 2 takes up this interpretation and states that 'he keeps on moaning about things', and simultaneously several professionals repeat the word 'moan' in the background. Esa is categorised as a moaner who is inclined to find fault with everything. 'Moaner' is a characterisation which is culturally clearly defined as an attitude based on personal choice. In the final turn the way of accounting changes again. Professional 3 does not contest the interpretation of moaning, but she begins to explain it as a learned propensity, which mitigates the blame put on the client and thus functions as an excuse. In formulating the cause as a matter of learning, the interpretation again indirectly makes the professionals themselves responsible. In the future, Esa ought perhaps to be trained to adopt a different and less negative attitude. A similar shifting is shown in the following excerpt.

\section{Excerpt 8}

P2: then if we move on to Antti Jokela I think we have to get Antti to shape up somehow he completely disregards all agreements as to schedules like now for example he's sent me a message that I won't be coming until twelve thirty even though that had been agreed

P3: he keeps chopping and changing

P2: today he stood behind the door waiting at half past seven so he doesn't nothing sticks at all whatever you've agreed with him it never sticks

P1: he can't

P2: yes but that's the thing that we're starting to apply the community method which means [which means 
P1: [he'll be punished

P2: oh no, we'll start we'll start

P1: repr- no what was it

P4: [reprimanding him giving him a talking-to

P2: [reprimand like starting out from talking about this reviewing this in the next unit [meeting

P1: [Yes

P2: reviewing the rules this unit has ((in a loud, annoyed voice))

In the first turn Professional 2 defines the client's troublesome behaviour as consisting of breaking the unit rules. At the same time, she produces an account for the behaviour that is based on the client's way of life and perhaps his attitudes as well. Her interpretation is supported by Professional 3 in the second turn. The image beginning to form is that of a client who disregards agreements about times and changes them according to his own wish. As the conversation progresses, alternatives to this client-blaming account are produced. Professional 1's comment, 'he can't', suggests that the client is lacking in skills that would allow him to keep to agreed times. Furthermore, in this excusing account, explanation is sought in the unit's own activity, though in fact this was already started during the first turn by the words 'we have to get Antti to shape up somehow'. The tool for getting Antti to shape up is produced in Professional 2's turn, where he says 'that we're starting to apply the community method'. The community method is something clearly shared by the professionals and is stressed in the official working principles of the unit. The conversation can be interpreted as self-blaming by the professionals in the sense that until now they have not been strict enough about breaking rules, have not used the community method frequently enough and have not made the rules clear enough for the clients. That is why these rules have to be taken as a topic in the next unit meeting. The professionals look at themselves in the mirror, as it were, and discuss whether their own laxness has made the 
infringements by Antti and others possible. In so doing the professionals also define Antti as someone who is, in principle, capable of following the rules, as long as the professionals enforce them strictly enough.

The analysis of Excerpts 7 and 8 highlight how different ways of accounting may come up in the course of conversations, even when discussing one client's case and his troublesome behaviour. Accordingly there is shifting between blames, excuses and responsibility. Those to be excused, blamed and made responsible can be both clients and others, including the professionals themselves.

\section{DISCUSSION}

This analysis has shown how professionals have various ways of accounting for their clients' troublesome behaviour. Firstly, explanations draw on three ways of accounting, which combine blame, excuses and responsibility in different ways. Secondly and following from the first point, the same troublesome behaviour can be accounted for in several ways. This shift can take place in the course of meeting conversations, when, for example, one professional blames the client himself for his lack of commitment towards the unit and another professional counters that the unit's own modes of action might cause this undesirable situation. Thirdly, due to these interactions, blameworthiness is divided between several actors; the clients, their informal or formal networks or the professionals themselves working in the unit.

There is no doubt that increasing the clients' responsibility is the main professional aim in the supported housing unit. After all, the unit was founded to rehabilitate people suffering both from 
mental health and substance abuse problems. This overall aim does not mean, however, that the professionals would one-sidedly blame their clients for their lack of responsibility. On the contrary, they also see blameworthiness in themselves and in other actors involved with the clients. All in all, what the professionals do in meeting conversations when accounting for their clients' troublesome behaviour is to shift and balance between blaming, excuses and responsibility. This shifting creates an idea of shared responsibility, as different versions of the client's blameworthiness are compared and provide direction for working with the client. This is extremely important these days, when the citizens' personal responsibility for their own lives is stressed at the expense of public responsibility in a politically hegemonic welfare state discourse in Finland (see Julkunen, 2006; Jokinen \& Juhila, 2008).

When doing accounting, the professionals inevitably construct categories and make moral judgements (Hall et al., 2006: 20-22; Urek, 2005; White, 2003). For instance, in the 'blaming the clients' account, the client might be categorised as an uncaring person with no wish to change his own life situation. Or, in the 'excusing the clients' account, the client category can be a sick person with no capacities to improve his own situation. Moral judgements in these accounts are tied with interpretations related to responsibility. For instance, an uncaring person lacks a personal feeling of responsibility, which is a morally judged attitude, while a sick person cannot be fully responsible and thus similarly should not be morally judged (cf. Watson, 1978). Moral judgements also serve as justifications for making certain interventions in the clients' lives. If the client is interpreted as lacking a personal feeling of responsibility, this justifies a disciplinary intervention, while in the case of a sick person, an intervention based on care is more easily argued for. However, it is also evident that the depiction of the client can be fluid as well as categorical. Various versions of the clients' character are available and may change over time. 
Analysis of the changing depiction of the client over several meetings may see shifting versions of the client, what has been described as 'unfinalized characters' (Hall, 1997: 203).

On reading these findings, it might be suggested that the workers here are acting unprofessionally by making assessments of clients on the basis of moral accounting. That depicting people in terms which blame or mitigate is inappropriate, since their professional ethics emphasize self determination, choice and empowerment, what Adams (1996: 2) describes as 'the central emerging feature of social work'. Our view is, however, that such 'practical-moral reasoning' (White \& Stancombe, 2003: 78) is an inevitable feature of everyday professional work and ethical concepts must be talked into existence in everyday communication.

Account analysis conducted in this paper belongs to discursive and ethnomethodological approaches in human service studies, which operate between two major approaches to practice: evidence-based practice and structural constraint. The extreme version of these positions might be characterised as follows. The former draws on scientific models like developmental psychology to locate professional practice as 'evidence-based' and interventionist. It attempts to assess needs of clients against particular expectations, and provides services which are measured against particular outcomes (White and Stancombe, 2003). In these models self determination is secondary to professional assessments of need and safety, which are dependent on technical issues for implementation. The latter draws on social theories of determinism and structure. They see both professional and client as constrained by subject positions which severely limit opportunities for choice and self determination. Inequalities, bureaucratic control and limited power mean that the opportunities for change are restricted. Pease (2002: 136) for example notes that 'empowerment' is in fact part of new managerial practices rather than a challenge to them. 
More fundamentally, the language available to speakers means that only certain things can be said since everyone is a product of deterministic structural processes.

Analysis in this study aims to recognise both the constraints on the client and the professional, but also the opportunities for local innovation. Blommaert (2005: 104) aims to link sociolinguistics with the work of Foucault:

The message offered by Foucault may sound somewhat gloomy: we are not all that free and operate within boundaries of the sayable and the hearable. But that does not eliminate creative practice (...) discursive practices are inherently creative, for the meanings that are (dialogically) constructed cannot be explained by reference to the latent potential of the speakers alone.

Discourse analysis and ethnomethodology are often reluctant to move beyond the data to engage with questions of practice and structure (Lynch, 1997). However this analysis displays how both disciplinary and caring forms of intervention are instances of control by the professionals. The persons cared for are considered to require control because otherwise they could not manage their lives. Disciplinary control, on the other hand, is justified by arguing that without it, the clients will break the common rules of the unit. In both cases the control is defined as being in the clients' best interest. The conversations during the meetings allow the conclusion that when the professionals assume responsibility for the clients' troublesome behaviour, they often end up saying that the clients must be controlled more strictly. In other words, the professionals define it as their own fault that they have not enforced the unit's rules strictly enough or that they have not consistently monitored and supported the progress of the client's rehabilitation (see Excerpts 7 
and 8). This way of arguing contains a serious ethical dilemma: when the professional take more responsibility for the clients' troublesome behaviour they simultaneously justify increasing control over the clients. It is clear that the workers in the studied unit are committed to principles like self determination and choice. However, everyday practice does not come along with proscriptions of how such principles are to be implemented in everyday situations. As Segal et al. (1993: 706) note: 'the absence of empowerment is easy to notice but its presence is difficult to define'.

In the end it may be asked why accounting for the clients' troublesome behaviour is so heavily present in the meeting talk. Who are the addressees of this talk: what and who are controlling the professionals own everyday work? Firstly, the addressees are the professionals themselves. The institutional task of the professionals is to rehabilitate clients towards something that is as close to 'normal living' as possible. The clients' troublesome behaviour is usually understood as setbacks in reaching this normalisation goal. Accounting is needed in order to find causes and thereby remedies for unwanted behaviour. In this sense, accounting is an integral part of everyday professional practices. When accounting for something to each other, the professionals are at the same time making visible the institutional task and the problems in achieving it. Secondly, account talk is also addressed to a wider audience than just the participants in situ, what Bakhtin (1986: 126) describes as the 'superaddressee' (see Hall 1997: 58). The professionals are accountable for their work to the supported housing unit's executive group and ultimately also to the municipality which purchases the service. The unit has to produce good enough results in its rehabilitation task, as otherwise its existence might be called into question. Although these latter addressees are not present as real persons at the meetings, their assumed 
demands regarding the results of the work are. This is an accountability which publicly financed human service workers cannot avoid.

Maynard (1988: 317) writes that language and interaction can operate as a site for exercise of control and dominance. However, control and dominance are not understood as due to external structural patterns that are automatically reproduced in interaction. Instead they are studied as participants' accomplishments. On the basis of our analysis it can be argued that the professionals produce elements of the clients' control and dominance in their accounts of the clients' troublesome behaviour. They produce causes for the clients' behaviours and in this sense use power. But power is also constraining them when they construct explanations for not being able to fulfil the aim of normalising the clients. By explanations like that they orient to institutional and structural constrains of their work. Accounting is an inherent part of all human service practices as it is part of social interaction in general, but 'whats' and 'hows' of accounting vary in different settings. An important critical question based on this study is whether blaming clients and making them as responsible for their own situation is been played out along with increasing managerialist and audit pressures to produce effective and economical rehabilitation (Saario \& Raitakari, 2008.; Matareese, 2008.). This way of accounting could provide an excuse for professionals for not being able to reach the anticipated results. However, whether this will be the case should be investigated with empirical follow-up study based on similar interactional data, not only by appealing 'external' structural changes.

In this text, we have read and analysed the professionals' ways of accounting. What we have not heard are the clients' voices. It would be the object of another study to explore the accounts which the clients would produce when explaining their own troublesome behaviour. Would they 
agree or disagree with the professionals' accounts? It might even be that they would define troubles differently. The gaps between actions and expectations could be in different places or might not exist at all.

\section{Acknowledgements}

The article is part of the research projects 'Dilemma between Control and Support in Social Work Practices' and 'The Categorization of the most Difficult Cases in Social Work Practices' funded by the Academy of Finland and conducted in the Department of Social Policy and Social Work at the University of Tampere. We would like to acknowledge the important contribution of the other members of the projects to this text, and comments from colleagues in the international research group DANASWAC.

\section{References:}

Adams, Robert (1996) Social Work and Empowerment. London: Macmillan

Antaki, Charles (1994) Explaining and Arguing: The Social Organization of Accounts. London: Sage Publications.

Auburn, Timothy \& Lea, Susan (2003) 'Doing Cognitive Distortions: A Discursive Psychology Analysis of Sex Offender Treatment Talk', British Journal of Social Psychology 42(2): 281-298.

Baistow, Karen (1994) 'Liberation or regulation? Some Paradoxes of Empowerment', Critical Social Policy 14: 34-46

Bakhtin, Mikhail (1986) Speech Genres and other Late Essays. Austin: University of Texas Press

Blommaert, Jan (2005) Discourse: A Critical Introduction. Cambridge: Cambridge University Press

Buttny, Richard (1993) Social Accountability in Communication. London: Sage Publications.

Buttny, Richard (1996) 'Clients' and Therapist's Joint Construction of the Clients' Problems', Research on Language and Social Interaction 29(2), 125-153.

Buttny, Richard (2004) Talking Problems: Studies on Discursive Construction. Albany: State University of New York Press. 
Buttny, Richard \& Ellis, Donald G. (2007) 'Accounts of Violence from Arabs and Israelis on Nightline', Discourse \& Society 18(2): 139-161.

D'cruz Heather (2004) 'The Social Construction of Child Maltreatment', Journal of Social Work 4(1), 99-123.

Eglin, Peter \& Hester, Stephen (2003) The Montreal Massacre: A Story on Membership Categorization Analysis. Waterloo: Wilfrid Laurier University Press.

Garfinkel, Harold (1967) Studies in Etnomethodology. Cambridge: Prentice-Hall.

Goffman, Erving (1959) The Presentation of Self in Everyday Life. Garden City, N.Y.: Anchor Books.

Goffman, Erving (1983) ‘The Interaction Order’, American Sociological Review 48: 1-17.

Hall, Christopher (1997) Social Work as Narrative: Storytelling and Persuasion in Professional Texts. Aldershot: Ashgate

Hall, Chistopher \& Juhila, Kirsi \& Parton, Nigel \& and Pösö, Tarja (eds.) (2003) Constructing Clienthood in Social Work and Human Practices: Interaction, Identities and Practices. London: Jessica Kingsley Publishers.

Hall, Christopher \& Slembrouck, Stef \& Sarangi, Srikant (2006) Language Practices in Social Work: Categorisation and Accountability in Child Welfare. London: Routledge.

Jokinen, Arja \& Juhila Kirsi \& Pösö Tarja (eds.) (1999) Constructing Social Work Practices. Aldershot: Ashgate.

Jokinen, Arja \& Juhila, Kirsi (eds.) (2008) Sosiaalityö aikuisten parissa [Social Work among Adults]. Tampere: Vastapaino.

Julkunen, Raija (2006) Kenen vastuu? Hyvinvointivaltion rajat ja julkinen vastuu [Whose Responsibility? The Limits of the Welfare State and Public Responsibility]. Helsinki: Stakes.

Juhila, Kirsi (2003) 'Creating a 'Bad' Client: Disalignment of Institutional Identities in Social Work'Interaction', in Christopher Hall, Kirsi Juhila, Nigel Parton \& Tarja Pösö (eds) Constructing Clienthood in Social Work and Human Services: Interaction, Identities and Practices, pp. 83-95. London: Jessica Kingsley Publishers.

Juhila, Kirsi (forthcoming)' From Care to Fellowship and Back: Interpretative Repertoires Used by the Social Welfare Workers when Describing their Relationship with Homeless Women', British Journal of Social Work 2007; doi: 10.1093/bjsw/bcm092. 
Kurri, Katja \& Wahlström, Jarl (2005) 'Placement of Responsibility and Moral Reasoning in Couple Therapy', Journal of Family Therapy 27(4): 352-369.

Lynch, Michael (1997) 'Ethnomethodology without Indifference', Human Studies 20(3): 371376.

Matarese, Maureen T. (2008) 'Help Me Help You: Reciprocal Responsibility in CaseworkerClient Interaction in a New York City Shelter', paper presented in The Fifth DANASWACseminar, August $19^{\text {th }}-20^{\text {th }} 2008$.

Maynard, Douglas W. (1988) 'Language, Interaction and Social Problems', Social Problems 35(4): 311-334.

Mäkitalo, Åsa (2003) 'Accounting Practices in Situated Knowing: Dilemmas and Dynamics in Institutional Categorisation', Discourse Studies 5(4): 495-516.

Nikander, Pirjo (2003) 'The Absent Client: Case Description and Decision Making in Interprofessional Meetings', in Christopher Hall, Kirsi Juhila, Nigel Parton \& Tarja Pösö (eds) Constructing Clienthood in Social Work and Human Services: Interaction, Identities and Practices, pp. 112-128. London: Jessica Kingsley Publishers.

Nikander, Pirjo (forthcoming) 'Working with Transcripts and Translated Data', Qualitative Research in Psychology, special issue on 'Teaching Qualitative Methods'.

Parker, Jonathan (2005) 'Constructing Dementia and Dementia Care', Journal of Social Work $5(3), 261-278$.

Pease, Bob (2002) 'Rethinking Empowerment: A Postmodern Reappraisal for Emancipatory Practice', British Journal of Social Work 32(2): 135-147.

Pithouse, Andrew (1985) 'Poor Visibility: Case Talk and Collegial Assessment in a Social Work Office', Work and Occupations 12(1): 77-89.

Pithouse, Andrew (1987) Social Work: The Social Organization of Invisible Trade. Aldershot: Avebury Gower.

Pomerantz, Anita (1978) 'Attributions and Responsibility: Blamings', Sociology 12(1): 115-121.

Potter, Jonathan (1996) Representing Reality: Discourse, Rhetoric and Social Construction. London: Sage Publications.

Potter, Jonathan \& Wetherell, Margaret (1987) Discourse and Social Psychology: Beyond Attitudes and Behaviour. London: Sage Publications. 
Raitakari, Suvi (2008) 'Asukkaasta kiinnipitäminen ja irtipäästäminen: Neuvotteluja yhteisön tavoittelemasta jäsenyydestä' ['Stand by and Let Go: Negotiations for Eligible Membership in Institutional Community'], in Irene Roivainen, Marianne Nylund, Riikka Korkiamäki \& Suvi Raitakari (eds) Yhteisöt ja Sosiaalityö: Kansalaisen vai asiakkaan asialla? [Communities and Social Work: On Behalf of Citizens or Clients?], pp. 225-244. Jyväskylä: PS-kustannus.

Riemann Gerhard (2005) 'Trying to Make Sense of Cases: Features and Problems of Social Workers' Case Discussions', Qualitative Social Work 4(4): 413-430.

Saario, Sirpa \& Raitakari, Suvi (2008) 'Purchase-Provider Model and Mental Health Rehabilitation: A Study of Practitioners' Effectiveness Arguments in a Supported Housing Unit, paper presented in The Fifth DANASWAC-seminar, August $19^{\text {th }}-20^{\text {th }} 2008$.

Sariola, Esa \& Ojanen, Markku (2000) Hoito vai pakkohoito: miten autan skitsofrenia potilasta? [Treatment or Compulsory Treatment: How do I Help Schizophrenia Patient?].Otava: Helsinki.

Scott, Marvin B. \& Lyman, Stanford M. (1968) 'Accounts', American Sociological Review 33(1): 46-62.

Segal, Steven, Silverman, Carol and Temkin, Tanya (1993) 'Empowerment and Self Help Agency: Practice for People with Mental Disabilities', Social Work 38(6): 705-712

Silverman, David (1987) Communication and Medical Practice: Social Relations in the Clinic. London: Sage.

Silverman, David (2007) A Very Short, Fairly Interesting and Reasonably Cheap Book about Qualitative Research. London: Sage.

Slembrouck, Stef \& Hall, Christopher (2003) 'Caring but Not Coping: Fashioning the Legitimate Parent Identity', in Christopher Hall, Kirsi Juhila, Nigel Parton \& Tarja Pösö (eds) Constructing Clienthood in Social Work and Human Services: Interaction, Identities and Practices, pp. 44-61. London: Jessica Kingsley Publishers.

Smith, Dorothy (1978) 'K is Mentally Ill: the Anatomy of a Factual Account', Sociology 12(1): 23-53.

Stancombe, John \& White, Sue (2005) 'Cause and Responsibility: Towards an Interactional Understanding of Blaming and 'Neutrality' in Family Therapy', Journal of Family Therapy 27(4): 330-351. 
Urek, Mojca (2005) 'Making a Case in Social Work: The Construction if an Unsuitable Mother', Qualitative Social Work 4(4): 451-467.

Watson, D. R. (1978) 'Categorization, Authorization and Blame: Negotiation in Conversation', Sociology 12(1): 105-113.

White, Sue (2002) 'Accomplishing 'the case' in Paediatrics and Child Health', Sociology of Health and Illness 24(4): 409-435.

White, Sue (2003) 'The Social Worker and a Moral Judge: Blame, Responsibility and Case Formulation', in Christopher Hall, Kirsi Juhila, Nigel Parton \& Tarja Pösö (eds) Constructing Clienthood in Social Work and Human Services: Interaction, Identities and Practices, pp. 177-192. London: Jessica Kingsley Publishers,.

White, Sue \& Stancombe, John (2003) Clinical Judgement in the Health and Welfare Professions: Extending the Evidence Base. Maidenhead: Open University Press 